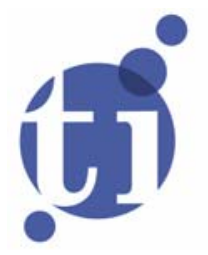

\title{
Social Network Sites, Individual Social Capital and Happiness
}

Efstratia Arampatzil

Martijn J. Burgerl,2

Natallia Noviki,3

' Erasmus School of Economics, Erasmus University Rotterdam, The Netherlands;

2 Tinbergen Institute, The Netherlands;

3 Université de Strasbourg, France. 
Tinbergen Institute is the graduate school and research institute in economics of Erasmus University Rotterdam, the University of Amsterdam and VU University Amsterdam.

More TI discussion papers can be downloaded at http://www.tinbergen.nl

Tinbergen Institute has two locations:

Tinbergen Institute Amsterdam

Gustav Mahlerplein 117

1082 MS Amsterdam

The Netherlands

Tel.: +31(0)20525 1600

Tinbergen Institute Rotterdam

Burg. Oudlaan 50

3062 PA Rotterdam

The Netherlands

Tel.: +31(0)10 4088900

Fax: +31(0)10 4089031 


\title{
Social Network Sites, Individual Social Capital and Happiness
}

\author{
Efstratia Arampatzi, M.Sc. \\ Erasmus Happiness Economics Research Organization (EHERO), Erasmus University Rotterdam. \\ E-mail: arampatzi@ese.eur.nl \\ Martijn J. Burger, Ph.D. \\ Corresponding author: Erasmus School of Economics, Department of Applied Economics and \\ Erasmus Happiness Economics Research Organization (EHERO), Erasmus University Rotterdam \\ and Tinbergen Institute, Postbus 1738, 3000 DR Rotterdam. Tel: +31 (0)10 4089579. Fax: +31 (0)10 \\ 4089141. E-mail: mburger@ese.eur.nl. URL: http://www.mjburger.net.
}

Natallia Novik, M.Sc.

Faculté des Sciences Économiques et de Gestion, Université de Strasbourg and Erasmus Happiness Economics Research Organization (EHERO), Erasmus University Rotterdam.

\section{Forthcoming in Journal of Happiness Studies}

\begin{abstract}
Can online social contacts replace the importance of real-life social connections in our pursuit of happiness? With the growing use of social network sites (SNSs), attention has been increasingly drawn to this topic. Our study empirically examines the effect of SNS use on happiness for different subgroups of young adults. More specifically, we examine whether the effect of SNSs on happiness is moderated by individual social capital, as measured in terms of frequency of social contacts and feelings of loneliness. Using Dutch data from the Longitudinal Internet Studies for the Social Sciences (LISS panel), we provide robust empirical evidence that there is, on average, no relationship between the amount of time spent on SNSs and happiness. However, we find a negative association between the numbers of hours spent on SNS and happiness for SNS users who feel socially disconnected and lonely. The results hold when we control for socio-demographic characteristics, trust, hours spent on other Internet sites and household income. Hence, SNSs are not a substitute for real-life social connections and, at most, complement them.
\end{abstract}

Keywords: Subjective well-being, happiness, social network sites, individual social capital, social isolation, loneliness

JEL Classification Codes: I31, L86, Z13 


\section{Social Network Sites, Individual Social Capital, and Happiness}

Happiness is currently considered one of the most important individual goals in human life. This pursuit of happiness calls for comprehension of the conditions that are necessary for a good life; thus, the subject has received considerable attention in the academic literature (Layard, 2005; Veenhoven, 2015): One of the key factors that affect happiness is the level of individual social capital, or an individual's pattern and intensity of social contacts with other people. In this regard, several studies have reported a positive association between individual social capital and the different components of subjective well-being, including happiness and life satisfaction ${ }^{1}$ (e.g., Helliwell and Barrington-Leigh 2010; Van der Horst and Coffé 2012; Portela et al. 2013; Ateca-Amestoy et al. 2014; Rodríguez-Pose and Von Berlepsch 2014).

However, several scholars have recently expressed strong concerns about declining levels of individual social capital - or the quality and quantity of social relationships - in Western countries. ${ }^{2}$ Most notably, in his seminal work Bowling Alone, Putnam (2000) argues that over the past decades, people in the United States have become increasingly disconnected from one another to the point that traditional civic, social and fraternal organizations have experienced a decline in membership. Research by MacPherson et al. (2006) shows that the number of confidants with whom Americans discuss important matters decreased by approximately one-third between 1985 and 2004. Although such declining trends in individual social capital have been identified in Europe to only a limited extent (e.g., Scheepers and Janssen 2003; Adam 2008; Sarracino 2010), on both sides of the Atlantic, there

\footnotetext{
${ }^{1}$ Following Diener et al. (1999), subjective well-being is a broad concept that encompasses 'people's emotional responses, domain satisfactions, and global judgments of life satisfaction'. In this article, we predominantly focus on global judgments, using overall happiness as the dependent variable.

${ }^{2}$ Following Portes (2000), social capital has both individual dimensions (e.g., relationships and reciprocity) and collective dimensions (e.g. trust and social cohesion). In this research, we focus predominantly on the individual dimensions of social capital in general and on social connections in particular.
} 
are increasing concerns that social isolation and loneliness are reducing happiness in modern Western society (De Jong Gierveld et al. 2006). Because a lack of social connectivity is associated with negative health outcomes (Cacioppo and Patrick, 2008), the World Health Organization has argued that social isolation and loneliness will be major challenges in the coming thirty years.

On the bright side, other scholars have argued that online communication, such as activity on social network sites (SNSs) such as Facebook and Twitter (see Boyd and Ellison, 2007), is gradually replacing traditional social interactions such as face-to-face communication and that, hence, the extent to which we are experiencing a decline in individual social capital remains questionable. Related to the previous point, several studies have reported a positive relationship between the use of SNSs and individual social capital (e.g., Ellison et al. 2007; Steinfield et al. 2008; Valenzuela et al. 2009; Johnston et al. 2013; Sabatini and Sarracino 2014).

Nevertheless, there is growing concern that computer-mediated communication is less socially and emotionally satisfying than face-to-face interaction (Turkle 2012), and the evidence found in studies that have examined the relationship between SNSs and subjective well-being has been inconsistent at the minimum. Studies by Kim and Lee (2011) and Manago et al. (2012) find a positive relationship between SNS use and subjective well-being, while research by Helliwell and Huang (2013) and Lönnqvist and Itkonen (2014) find no relationship between SNS use and subjective well-being. Kross et al. (2013) find that Facebook use predicts declines in happiness and life satisfaction among young adults, while Sagioglou and Greitemeyer (2014) report that Facebook activity negatively affects people's happiness. In particular, it has been found that the use of Facebook can trigger negative emotions such as jealousy, social tension, and social overload (Krasnova et al. 2013).

One reason for these ambiguous results is that the relationship between SNS use and subjective well-being likely involves both positive and negative effects, the balance of which is likely to vary across people and environments. In the current article, we argue that particularly for people 
who lack individual social capital, i.e., those characterized by social isolation, dissatisfaction with social contacts and social loneliness, SNS activity has a negative effect on subjective well-being. Here, social isolation is defined as the objective physical separation from other people, such as infrequent contact with friends or family. In contrast to social isolation, social loneliness is often regarded as an unfavourable balance between the actual and desired social contact (Ernst and Cacioppo 1999) and, hence, the more subjective feeling of being alone, such as feeling socially lonely and dissatisfied with one's social contacts. In this paper, we argue that SNS activity has a different effect on the happiness of people who lack individual social capital compared to people who have more abundant individual social capital because these two groups use and experience SNSs differently. These differences in usage and experience are related to both active participation and passive following behaviour on SNSs:

Active participation on SNSs mainly involves posting, commenting, liking and chatting and is generally found to be positively related to subjective well-being because of the positive effects of active sharing and communication on subjective well-being (Lee et al. 2011; Wang 2013). However, active participation can negatively affect subjective well-being through frequent negative posting (Locatelli et al. 2012). Although SNSs can provide a substitute for face-to-face interaction for socially isolated and lonely people and can thus enhance their well-being, socially isolated and lonely people tend to post more negative items compared with non-isolated and non-lonely people (see also Jin, 2013), which negatively affects their levels of well-being. In addition to relatively more frequent negative posts, people who lack individual social capital may be unable to express their true self online (Reinecke and Trepte 2014) because of the social norms on SNSs that encourage the posting of predominantly positive status updates and messages. Positive status updates on SNSs are associated with higher social attractiveness of the sender (Antheunis et al. 2010; Bazarova 2012) and receive a larger number of reactions (Utz 2011) and more positive reactions (Forest and Wood, 2012) from SNS contacts. Because a lack of contact with friends and feelings of loneliness and dissatisfaction with 
social contacts is not perceived as positive or in line with social norms, people who lack individual social capital are not only less likely to feel authentic on SNSs but also receive less happiness from expressing their true self online (see also Reinecke and Trepte 2014). In this regard, it is not surprising that lonely people's satisfaction with Facebook was found to be lower than that of non-lonely people (Jin, 2013). Examining differences in active participation (experiences), we expect that the lack of individual social capital negatively moderates the relationship between SNS use and happiness.

Passive following refers to browsing other people's profiles and can enhance subjective wellbeing by building a sense of connectedness (Valenzuela et al. 2009) and serving as a pleasurable experience (Wise et al. 2010). However, the passive following of SNSs or the following of information that others share on the platform can negatively affect subjective well-being through exacerbation of negative emotions such as envy and jealousy. According to Krasnova et al. (2013) and Tandoc et al. (2015), scrolling through the status updates of others might give the impression that other people have a more enjoyable social life. Such social comparisons can aggravate feelings of envy and jealousy, which in turn decrease subjective well-being (Muise et al. 2009; Utz and Beukeboom 2011; Appel et al., 2016). For example, as SNS user might become envious of the many 'likes' on photos or birthday wishes that others receive or jealous about being the only individual who was not invited on a weekend trip. In particular, people who lack individual social capital are more prone to experiencing feelings of envy and jealousy because they already feel a lack of connectedness or communality and tend to attribute the positive content presented on a given SNS page to the owner's personality rather than to situational factors (Chou and Edge 2012). In this regard, several scholars have pointed to the link between loneliness and envy (Schoeck 1969; Ninivaggi 2010), while jealousy and envy are considered conventional emotional responses to social exclusion (Leary 1990). Hence, based on differences in passive following behaviour, we expect that a lack of individual social capital negatively moderates the relationship between SNS use and happiness. 
Building on the previous literature, the current study focuses on SNSs, individual social capital, and happiness using a representative sample of young adults (15-44 years old) in the Netherlands. In this research, happiness is regarded as one of the components of subjective well-being (Diener et al. 1999) that captures how much positive emotion people are experiencing, whereas individual social capital reflects the quantity (frequency) and quality (assigned value) of the social contacts people have. We first investigate the extent to which SNS use, measured as the amount of time spent on SNSs, provides a substitute for real-life interactions in terms of happiness. Second, we explore the heterogeneity in the relationship between SNS use and happiness by analysing the extent to which the association between SNS use and happiness is moderated by social isolation and loneliness. Unlike previous work and motivated by the mixed findings on the effect of SNS use on happiness, this article provides a better understanding of the conditions under which SNSs can positively or negatively affect happiness. Here, we expect that the happiness of young adults who lack social contacts, are dissatisfied with their social contact, and feel lonely is particularly negatively affected by spending an excessive amount of time on SNSs.

\section{Data and Methodology}

\subsection{Data and Variables}

To analyse the relationship between SNS use, individual social capital, and happiness among young adults (15-44 years), we used the Dutch Longitudinal Internet Studies for the Social Sciences (LISS) panel for the years 2012-2013. In the LISS survey, individuals report on several aspects of their life, including their happiness, Internet use, and individual social capital. Our sample included 1,339 
respondents who indicated that they ever used SNSs. ${ }^{3}$ Of these respondents, 605 individuals completed the survey in both 2012 and $2013 .^{4}$

\section{Happiness.}

In our research, happiness was measured using an 11-point scale of happiness in response to the question "On the whole, how bappy would you say you are?", 0 being equal to "totally unhappy" and 10 being equal to "totally happy". 5

\section{Activity on Online Social Network Sites.}

Our analysis included respondents who had ever engaged in online activities. We measured the respondents' online activity by reporting the average number of hours spent per week on SNSs. Here, SNS use is defined as the time spent on social media, such as Facebook, Hyves, Myspace, Sugababes, Twitter, or dating sites (such as Relatieplanet or Lexa). Respondents who reported an unrealistic number of hours per week ( $>168$ hours) spent on all online activities were excluded from the sample. To limit the effect of outliers, any extreme values in our SNS analysis were winsorized at the $99^{\text {th }}$ percentile.

\section{Lack of Individual Social Capital: Social Isolation and Loneliness.}

Individual social capital was measured by the quantity (frequency) and quality (assigned value) of social contacts with family and friends. The frequency of contacts was measured using the following two questions: (1) How often do you do the following: Spend an evening with family? (2) How often do you do the following: Spend an evening with friends? For both questions, the respondents could answer (1) almost

\footnotetext{
${ }^{3}$ Of the full sample, $73 \%$ of the respondents (15-44 years) indicated that they had ever spent time on social network sites.

${ }^{4}$ The panel was extracted from the LISS database and uses information from 3 panels of the core study: "Personality Questionnaire-LISS Core Study", "Social Integration and Leisure Questionnaire, LISS Core study", and "Demographics Questionnaire". The decrease in sample size is caused by the fact that only a limited (random) sample was asked to complete the questionnaire on online social network usage in 2013. Hence, there is indication of panel attrition bias. ${ }_{5}$ The LISS survey also includes a life satisfaction question that asks respondents "How satisfied are you with the life you lead at the moment (on a scale of 0-10)?" The correlation between happiness and the life satisfaction variable in our sample is very high (0.82). The results of this life satisfaction indicator are therefore not presented in the article but led us to the same conclusions, which are available on request.
} 
every day, (2) once or twice per week, (3) a few times per month, (4) about once per month, (5) a number of times per year, (6) about once per year, (7) never, (8) don't know, or (9) not applicable. Because social isolation is considered the situation of almost never or never seeing family or friends, the categories were aggregated to (i) a few times per week to about once per month (labelled "frequent contacts with family or friends") and (ii) a number of times per year to never (labelled "infrequent contacts with family or friends") (cf. Forsman et al. 2012). ${ }^{6}$ Respondents who answered "don't know" or "not applicable" were excluded from our sample. ${ }^{7}$ Regarding loneliness embodied in the experienced quality of face-to-face interaction, we included subjective measures of satisfaction with contacts and social loneliness. Satisfaction with contacts was measured using the following question (with responses on a scale of 1-10): How satisfied are you with your social contacts? Social loneliness was measured using the social loneliness index suggested by De Jong Gierveld and Van Tilburg (2006, 2010), which is also used in Toepoel (2013). This index is based on the following items: (i) There are enough people I can count on in case of a misfortune (yes/don't know/no), (ii) I know many people on whom I can completely rely (yes/don't know/no), and (iii) There are enough people to whom I feel closely connected (yes/don't know/no). Cronbach's alpha (0.75) indicated that the index is internally consistent.

\section{Control Variables.}

In our analysis, we included control variables that could confound the relationships among SNS use, individual social capital and happiness. The control variables included in the analysis were other time spent online, online gaming, trust in other people (i.e., collective social capital), gender, age, civil

\footnotetext{
${ }^{6}$ Please note that data were aggregated because there were few young adults in the sample who indicated that they were seeing friends very frequently or seeing friends never or only a few times per year. When re-estimating our baseline regressions (Table 3) using the frequency of contacts as continuous variable, the main conclusions do not change. These results are in Appendix B, Table 1.

${ }^{7}$ The categories "Don't know" and "Not Applicable" were completed by fewer than $3.2 \%$ and $1.5 \%$ of the respondents, respectively.
} 
status, education, occupation and household income. The control variables were chosen on the basis of being potentially important confounders of the relationship between SNS use, individual social capital and happiness and/or being commonly regarded as important determinants of happiness (Layard 2005).

Table 1: Descriptive Statistics

\begin{tabular}{|c|c|c|c|c|c|}
\hline & $\mathrm{N}$ & Mean & Std. Dev. & Min & Max \\
\hline \multicolumn{6}{|l|}{ Outcome variable } \\
\hline Happiness & 1944 & 7.49 & 1.21 & 0 & 10 \\
\hline \multicolumn{6}{|l|}{ Independent variables } \\
\hline Time spent on social network sites (x10h) & 1944 & 0.49 & 0.83 & 0 & 4.0 \\
\hline Infrequent contact with friends & 1944 & 0.31 & 0.46 & 0 & 1 \\
\hline Infrequent contact with family & 1944 & 0.20 & 0.40 & 0 & 1 \\
\hline Social loneliness index & 1944 & 1.20 & 1.81 & 0 & 6 \\
\hline Satisfaction with social contacts & 1944 & 7.27 & 1.54 & 0 & 10 \\
\hline \multicolumn{6}{|l|}{ Control variables } \\
\hline \multicolumn{6}{|l|}{ Time spent online } \\
\hline Time spent on internet (other) (x10h) & 1944 & 1.65 & 1.41 & 0 & 7.6 \\
\hline Time spent on online games (x10h) & 1944 & 0.14 & 0.32 & 0 & 2.0 \\
\hline \multicolumn{6}{|l|}{ Collective social capital } \\
\hline Trust in people & 1944 & 6.06 & 2.04 & 0 & 10 \\
\hline \multicolumn{6}{|l|}{ Gender } \\
\hline Female & 1944 & 0.59 & 0.49 & 0 & 1 \\
\hline \multicolumn{6}{|l|}{ Age groups } \\
\hline 25-34 years old & 1944 & 0.31 & 0.46 & 0 & 1 \\
\hline $35-44$ years old & 1944 & 0.39 & 0.49 & 0 & 1 \\
\hline \multicolumn{6}{|l|}{ Occupational status } \\
\hline Unemployed & 1944 & 0.03 & 0.16 & 0 & 1 \\
\hline Employed & 1944 & 0.63 & 0.48 & 0 & 1 \\
\hline School & 1944 & 0.27 & 0.44 & 0 & 1 \\
\hline \multicolumn{6}{|l|}{ Civil status } \\
\hline Married & 1944 & 0.33 & 0.47 & 0 & 1 \\
\hline Separated/ Divorced & 1944 & 0.05 & 0.19 & 0 & 1 \\
\hline \multicolumn{6}{|l|}{ Income level } \\
\hline Household Income ( $€$ €1000) & 1944 & 3.10 & 1.54 & 0 & 13 \\
\hline \multicolumn{6}{|l|}{ Education } \\
\hline Medium level & 1944 & 0.44 & 0.50 & 0 & 1 \\
\hline High level & 1944 & 0.36 & 0.48 & 0 & 1 \\
\hline \multicolumn{6}{|l|}{ Year } \\
\hline 2013 & 1944 & 0.48 & 0.50 & 0 & 1 \\
\hline
\end{tabular}

The summary statistics and the correlation matrix of the variables included in the analysis can be found in Tables 1 and 2, respectively; a detailed description of the variables included in the analysis can be found in Appendix A, Table 1, and a frequency table of the categorical variables in our analysis can be found in Appendix A, Table 2. 
Table 2: Correlation Matrix of Main Variables Included in the Analysis

\begin{tabular}{|c|c|c|c|c|c|c|c|c|c|c|}
\hline & (1) & (2) & (3) & (4) & (5) & (6) & (7) & (8) & (9) & $(10)$ \\
\hline (1) Time spent on social network sites (x10h) & 1.00 & & & & & & & & & \\
\hline (2) Infrequent contact with friends & -0.08 & 1.00 & & & & & & & & \\
\hline (3) Infrequent contact with family & 0.01 & 0.19 & 1.00 & & & & & & & \\
\hline (4) Satisfaction with social contact & 0.01 & 0.19 & -0.14 & 1.00 & & & & & & \\
\hline (5) Social loneliness index & 0.09 & 0.14 & 0.14 & -0.44 & 1.00 & & & & & \\
\hline (6) Time spent on internet (other) (x10h) & 0.36 & 0.05 & -0.01 & -0.02 & 0.04 & 1.00 & & & & \\
\hline (7) Time spent on online games (x10h) & 0.21 & 0.01 & 0.05 & -0.00 & 0.06 & 0.23 & 1.00 & & & \\
\hline (8) Trust in people & -0.10 & -0.11 & -0.07 & 0.22 & -0.23 & 0.00 & -0.04 & 1.00 & & \\
\hline (9) Female & 0.03 & 0.04 & -0.01 & 0.01 & 0.01 & -0.17 & -0.15 & -0.03 & 1.00 & \\
\hline (10) Age: $25-34$ years old & -0.08 & -0.02 & -0.11 & 0.01 & -0.03 & 0.02 & -0.05 & 0.02 & 0.00 & 1.00 \\
\hline (11) Age: $35-44$ years old & -0.19 & 0.23 & 0.06 & -0.08 & 0.03 & -0.07 & -0.05 & -0.00 & 0.02 & -0.51 \\
\hline (12) Occupational status: Unemployed & 0.01 & 0.01 & 0.05 & -0.05 & 0.05 & 0.02 & -0.02 & -0.08 & -0.01 & 0.01 \\
\hline (13) Occupational status: Employed & -0.24 & 0.11 & -0.07 & -0.01 & -0.07 & -0.03 & -0.10 & 0.11 & -0.08 & 0.33 \\
\hline (14) Occupational status: School & 0.27 & -0.21 & 0.04 & 0.08 & 0.02 & 0.06 & 0.07 & -0.01 & 0.00 & -0.35 \\
\hline (15) Civil status: Married & -0.17 & 0.22 & -0.01 & -0.04 & 0.01 & -0.10 & -0.06 & 0.09 & 0.05 & 0.02 \\
\hline (16) Civil status: Separated/Divorced/Widowed & -0.06 & 0.04 & 0.05 & -0.10 & 0.06 & -0.01 & 0.01 & -0.05 & 0.03 & -0.04 \\
\hline (17) Household Income (x€1000) & -0.06 & -0.03 & 0.03 & 0.10 & -0.10 & -0.01 & -0.06 & 0.13 & -0.00 & -0.01 \\
\hline (18) Education: Medium level & 0.06 & 0.01 & 0.01 & 0.03 & -0.00 & -0.02 & 0.08 & -0.01 & 0.02 & 0.13 \\
\hline (19) Education: High level & -0.15 & 0.01 & 0.01 & 0.01 & -0.09 & 0.07 & -0.13 & 0.19 & 0.00 & 0.28 \\
\hline (20) Year: 2013 & 0.02 & 0.01 & 0.03 & 0.03 & 0.14 & 0.04 & 0.02 & -0.01 & -0.00 & -0.02 \\
\hline
\end{tabular}

Table 2 (continued)

\begin{tabular}{llllllll}
\hline & $(11)$ & $(12)$ & $(13)$ & $(14)$ & $(15)$ & $(16)$ & $(17)$ \\
(11) Age: 35-44 years old & 1.00 & & & $(18)$ & $(19)$ \\
(12) Occupational status: Unemployed & 0.03 & 1.00 & & & & & \\
(13) Occupational status: Employed & 0.32 & -0.22 & 1.00 & & & \\
(14) Occupational status: School & -0.45 & -0.10 & -0.80 & 1.00 & & \\
(15) Civil status: Married & 0.41 & -0.03 & 0.30 & -0.41 & 1.00 & \\
(16) Civil status: Separated/Divorced/Widowed & 0.17 & -0.10 & 0.07 & -0.11 & -0.14 & 1.00 \\
(17) Household Income (x€1000) & -0.02 & -0.06 & 0.10 & -0.03 & 0.11 & -0.06 & 1.00 \\
(18) Education: Medium level & 0.01 & 0.01 & -0.12 & 0.12 & -0.02 & 0.05 & -0.11 \\
(19) Education: High level & 0.05 & 0.01 & 0.35 & -0.33 & 0.11 & -0.03 & 0.15 \\
(20) Year: 2013 & -0.01 & 0.02 & -0.04 & 0.03 & 0.00 & 0.02 & -0.00 \\
\end{tabular}




\subsection{Empirical Strategy}

To analyse the relationships between SNS use, individual social capital, and happiness, we used a random effects model in which we considered that observations are clustered within individuals given the longitudinal structure of the dataset; for some individuals, we had observations at two points in time (2012 and 2013). A random effects estimator is preferred over a simple pooled linear regression (pooled OLS) because ignoring the clustering of observations within individuals can result in biased coefficients and standard errors (Hox 2002). We prefer a random effects estimator to a fixed effects estimator because the LISS data have a limited time dimension, information is not available at both time points for all individuals, and most of the variance is between individuals rather than within individuals. Hence, the use of a fixed effects estimator severely reduces the sample size, and variables can become statistically insignificant despite being economically significant. In addition, the measurement of our SNS use variable is known to be subject to memory distortion, in that individuals often have difficulty precisely recalling the average amount of time that they spent on specific activities (Pantic et al. 2012). Hence, we prefer to explore both the between- and within-individuals variation in SNS use rather than the within-individuals variation alone.

More specifically, we estimated the following random effects regression:

Happiness $_{\text {it }}=\Theta S N S U_{s e} e_{\text {it }}+\Omega$ Individual Social Capital $_{\text {it }}+\Psi$ (SNS Use it $\mathrm{x} \Omega$ Individual Social Capital $\left._{\text {it }}\right)$ $+\Sigma$ Control $_{\text {it }}+\mu_{\mathrm{i}}+\varepsilon_{\text {it }}$ 
where Happiness ${ }_{\text {it }}$ is the reported happiness of individual $i$ in year $t, S N S U s e_{\text {it }}$ is the average number of hours per week individual $i$ spends on online social network sites, Individual Social Capital ${ }_{\text {it }}$ is a vector of individual social capital variables for individual $i$ in year $\mathrm{t}$ and includes our measures of social isolation and loneliness, SNS Use it x $\Omega$ Individual Social Capital $_{\text {it }}$ denotes the interaction effect between SNS use and our individual social capital variables, Controlit is a vector of the control variables for individual $i$ in year $t, \mu_{\mathrm{i}}$ is the individual random effect, and $\varepsilon_{\mathrm{it}}$ is the residual error. We added the interaction effects between SNS use and the individual social capital variables because we expected social isolation and loneliness to moderate the relationship between SNS use and happiness. Hence, we expected the effect of SNS on happiness to differ for different levels of individual social capital. Accordingly, this relationship is contingent upon individual social capital rather than mediated by it.

\section{Empirical Results}

\subsection{Baseline Results}

Table 3 presents the results of our random effects estimation. All of our models were estimated using cluster-robust standard errors. Controlling for socio-demographic characteristics, trust, hours spent on other Internet sites, hours spent on online gaming and household income, we found no significant association between the use of SNS and happiness. At the same time, individual social capital affected happiness (Table 3, Columns 2-4). Although we found that infrequently meeting with friends was not significantly related to happiness, the young adults who infrequently met with family reported, on average, a 0.2-point lower happiness score when all else was held constant. There appears to be a strong association between social loneliness and happiness. The respondents who were satisfied with their social contacts and scored low on the social loneliness index were generally happier than the respondents who were dissatisfied with their social contacts and scored high on the social loneliness scale. Compared to the young adults who rated their satisfaction with social contacts as a 7 (on a scale 
from $0-10$ ), the young adults who rated their satisfaction with contacts as a 6 also reported, on average, a 0.22-point lower happiness score. Likewise, the respondents who scored 1 point higher on the social loneliness index (on a scale from 0-6) reported, on average, a 0.1-point lower happiness score. When all dimensions of social isolation and loneliness were included (Table 3, Column 7), we found no significant association between SNS use and happiness. We also observed that the quality of social capital rather than the quantity of social capital drove the variation in happiness. While we did not find that the frequency of meeting with family and friends had a significant effect on happiness, we observed a significant effect of satisfaction with contacts and social loneliness on happiness.

Nevertheless, the main goal of this study was to examine the extent to which social isolation and loneliness moderate the association between the time spent on SNSs and happiness. As shown in Table 4, social isolation did not moderate the relationship between SNS use and happiness ${ }^{8}$. The interaction effects between SNS use and infrequently meeting with friends (Table 4, Column 1) and SNS use and infrequently meeting with family were statistically insignificant (Table 4, Column 2). However, we found evidence that social loneliness moderates the relationship between SNS and happiness. Young adults who were not satisfied with their contacts and excessively used SNS were, on average, less happy than young adults who were not satisfied with their contacts and used SNS only to a limited extent (Table 4, Column 3). Likewise, young adults who scored high on the social loneliness scale and frequently used SNS were, on average, less happy than young adults who scored high on the social loneliness scale and did not use SNS frequently (Table 4, Column 4).

\footnotetext{
${ }^{8}$ As a robustness check, we estimated identical models treating the frequency of social contacts (both with friends and family) as continuous indicators, found in Appendix B, Table 2. The findings indicate that we can draw the same conclusions regarding the effects of objective indicators of individual social capital.

${ }^{9}$ When we include a robustness check for respondents in our analysis who have never used SNSs in their life, our main conclusions do not change. These results are available upon request.
} 
Table 3: Random effects estimation: SNS, Individual Social Capital, and Happiness

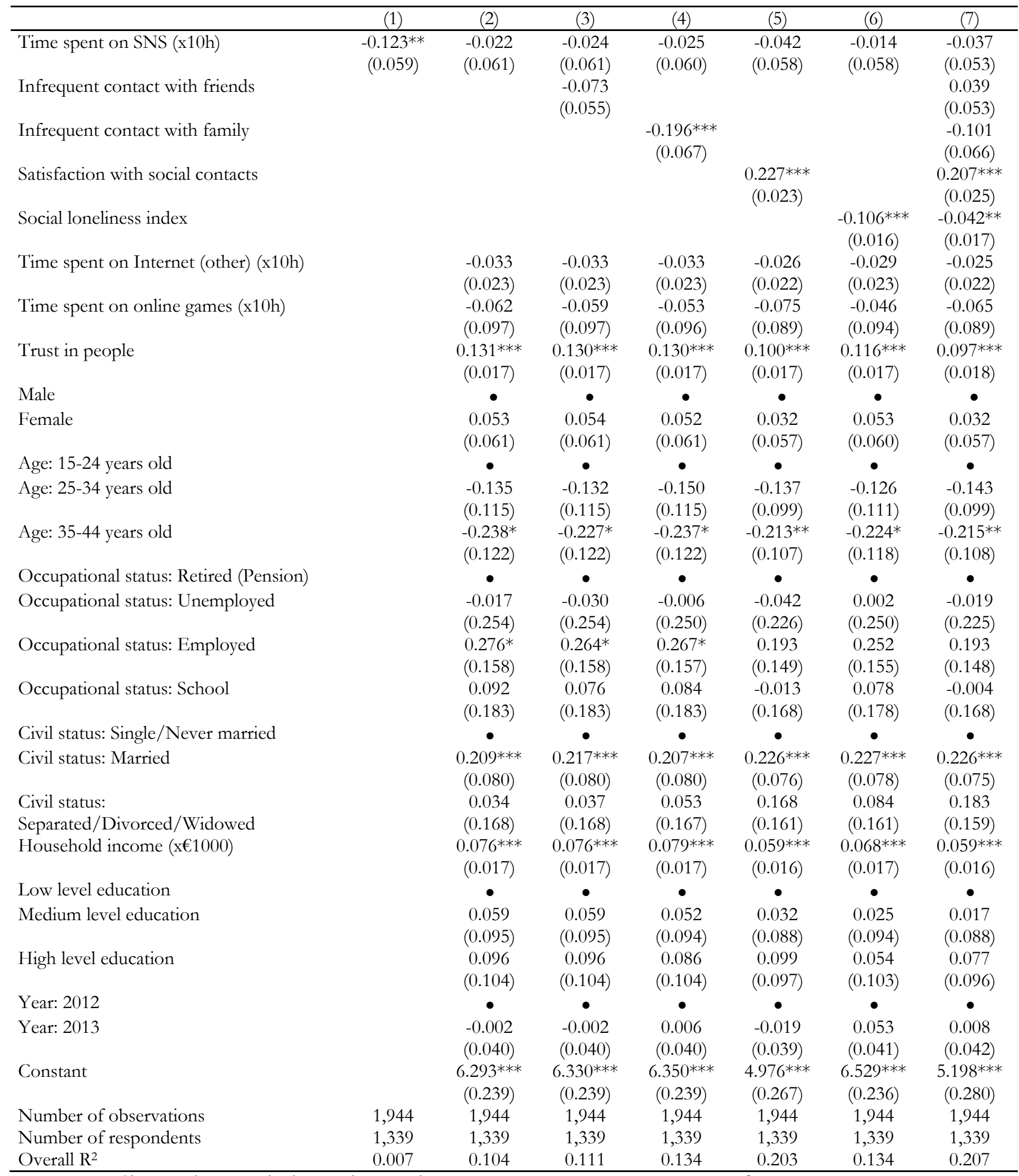

Notes: Cluster-robust standard errors in parentheses; ${ }^{* * *} \mathrm{p}<0.01,{ }^{* *} \mathrm{p}<0.05,{ }^{*} \mathrm{p}<0.10, \bullet$ Reference category 
Table 4: Random effects estimation: SNS and SWB. Moderation Analysis: 1) Frequency of contacts with family 2) Frequency of contacts with friends 3) Satisfaction with Contacts 4) Social Loneliness Index

\begin{tabular}{|c|c|c|c|c|}
\hline $\begin{array}{l}\text { Infrequent contact with friends* Time spent on } \\
\text { online social networks (x10h) }\end{array}$ & $\begin{array}{c}(1) \\
0.128 \\
(0.117)\end{array}$ & (2) & (3) & (4) \\
\hline $\begin{array}{l}\text { Infrequent contact with family* Time spent on } \\
\text { online social networks (x10h) }\end{array}$ & & $\begin{array}{l}-0.079 \\
(0.107)\end{array}$ & & \\
\hline $\begin{array}{l}\text { Satisfaction with contacts* Time spent on online } \\
\text { social networks (x10h) }\end{array}$ & & & $\begin{array}{c}0.065^{* *} \\
(0.027)\end{array}$ & \\
\hline $\begin{array}{l}\text { Social loneliness index* Time spent on online } \\
\text { social networks (x10h) }\end{array}$ & & & & $\begin{array}{c}-0.053^{* *} \\
(0.021)\end{array}$ \\
\hline Time spent on online social networks (x10h) & $\begin{array}{l}-0.066 \\
(0.054)\end{array}$ & $\begin{array}{l}-0.020 \\
(0.054)\end{array}$ & $\begin{array}{l}-0.025 \\
(0.049)\end{array}$ & $\begin{array}{c}0.000 \\
(0.050)\end{array}$ \\
\hline Infrequent contact with friends & $\begin{array}{l}-0.014 \\
(0.067)\end{array}$ & $\begin{array}{c}0.037 \\
(0.053)\end{array}$ & $\begin{array}{c}0.036 \\
(0.053)\end{array}$ & $\begin{array}{c}0.039 \\
(0.053)\end{array}$ \\
\hline Infrequent contact with family & $\begin{array}{l}-0.098 \\
(0.066)\end{array}$ & $\begin{array}{l}-0.063 \\
(0.084)\end{array}$ & $\begin{array}{l}-0.100 \\
(0.066)\end{array}$ & $\begin{array}{l}-0.104 \\
(0.066)\end{array}$ \\
\hline Satisfaction with social contacts & $\begin{array}{l}0.207 * * * \\
(0.025)\end{array}$ & $\begin{array}{c}0.207 * * * \\
(0.025)\end{array}$ & $\begin{array}{l}0.204^{* * *} \\
(0.025)\end{array}$ & $\begin{array}{l}0.205^{* * *} \\
(0.025)\end{array}$ \\
\hline Social loneliness index & $\begin{array}{c}-0.042^{* *} \\
(0.017)\end{array}$ & $\begin{array}{c}-0.042^{* *} \\
(0.017)\end{array}$ & $\begin{array}{c}-0.040^{* *} \\
(0.017)\end{array}$ & $\begin{array}{c}-0.038^{* *} \\
(0.017)\end{array}$ \\
\hline Time spent on Internet (other) (x10h) & $\begin{array}{l}-0.025 \\
(0.022)\end{array}$ & $\begin{array}{l}-0.026 \\
(0.022)\end{array}$ & $\begin{array}{l}-0.027 \\
(0.021)\end{array}$ & $\begin{array}{l}-0.027 \\
(0.022)\end{array}$ \\
\hline Time spent on online games (x10h) & $\begin{array}{l}-0.066 \\
(0.089)\end{array}$ & $\begin{array}{l}-0.059 \\
(0.089)\end{array}$ & $\begin{array}{l}-0.069 \\
(0.086)\end{array}$ & $\begin{array}{l}-0.066 \\
(0.087)\end{array}$ \\
\hline Trust in people & $\begin{array}{c}0.097 * * * \\
(0.017)\end{array}$ & $\begin{array}{c}0.098^{* * *} \\
(0.017)\end{array}$ & $\begin{array}{c}0.097 * * * \\
(0.017)\end{array}$ & $\begin{array}{c}0.096^{* * *} \\
(0.016)\end{array}$ \\
\hline Male & $\bullet$ & $\bullet$ & $\bullet$ & $\bullet$ \\
\hline Female & $\begin{array}{c}0.034 \\
(0.057)\end{array}$ & $\begin{array}{c}0.032 \\
(0.057)\end{array}$ & $\begin{array}{c}0.030 \\
(0.057)\end{array}$ & $\begin{array}{c}0.034 \\
(0.057)\end{array}$ \\
\hline Age: $15-24$ years old & $\bullet$ & $\bullet$ & $\bullet$ & $\bullet$ \\
\hline Age: $25-34$ years old & $\begin{array}{l}-0.149 \\
(0.099)\end{array}$ & $\begin{array}{l}-0.136 \\
(0.099)\end{array}$ & $\begin{array}{l}-0.105 \\
(0.096)\end{array}$ & $\begin{array}{l}-0.115 \\
(0.096)\end{array}$ \\
\hline Age: $35-44$ years old & $\begin{array}{c}-0.219 * * \\
(0.108)\end{array}$ & $\begin{array}{c}-0.208^{*} \\
(0.108)\end{array}$ & $\begin{array}{c}-0.179 * \\
(0.105)\end{array}$ & $\begin{array}{c}-0.190^{*} \\
(0.106)\end{array}$ \\
\hline Occupational status: Retired (Pension) & $\bullet$ & $\bullet$ & $\bullet$ & $\bullet$ \\
\hline Occupational status: Unemployed & $\begin{array}{l}-0.029 \\
(0.224)\end{array}$ & $\begin{array}{l}-0.021 \\
(0.225)\end{array}$ & $\begin{array}{l}-0.006 \\
(0.221)\end{array}$ & $\begin{array}{l}-0.002 \\
(0.224)\end{array}$ \\
\hline Occupational status: Employed & $\begin{array}{c}0.194 \\
(0.148)\end{array}$ & $\begin{array}{c}0.193 \\
(0.149)\end{array}$ & $\begin{array}{c}0.203 \\
(0.149)\end{array}$ & $\begin{array}{c}0.204 \\
(0.148)\end{array}$ \\
\hline Occupational status: School & $\begin{array}{l}-0.006 \\
(0.167)\end{array}$ & $\begin{array}{l}-0.000 \\
(0.168)\end{array}$ & $\begin{array}{c}0.032 \\
(0.165)\end{array}$ & $\begin{array}{c}0.024 \\
(0.165)\end{array}$ \\
\hline Civil status: Single/Never married & $\bullet$ & • & $\bullet$ & $\bullet$ \\
\hline Civil status: Married & $\begin{array}{c}0.227 * * * \\
(0.075)\end{array}$ & $\begin{array}{c}0.226^{* * *} \\
(0.075)\end{array}$ & $\begin{array}{c}0.224^{* * *} \\
(0.075)\end{array}$ & $\begin{array}{c}0.220^{* * *} \\
(0.075)\end{array}$ \\
\hline Civil status: Separated/Divorced/Widowed & $\begin{array}{c}0.187 \\
(0.159)\end{array}$ & $\begin{array}{c}0.179 \\
(0.159)\end{array}$ & $\begin{array}{c}0.166 \\
(0.159)\end{array}$ & $\begin{array}{c}0.170 \\
(0.159)\end{array}$ \\
\hline Household income $(x € 1000)$ & $\begin{array}{c}0.060^{* * *} \\
(0.016)\end{array}$ & $\begin{array}{c}0.059 * * * \\
(0.016)\end{array}$ & $\begin{array}{c}0.059 * * * \\
(0.016)\end{array}$ & $\begin{array}{c}0.060^{* * *} \\
(0.016)\end{array}$ \\
\hline
\end{tabular}




\section{Table 4 (Continued)}

Low level education

Medium level education

High level education

Year: 2012

Year: 2013

Constant

Number of observations

Number of respondents

Overall $\mathrm{R}^{2}$

$\begin{array}{cccc}\bullet & \bullet & \bullet & \bullet \\ 0.017 & 0.017 & 0.017 & 0.014 \\ (0.088) & (0.088) & (0.087) & (0.087) \\ 0.076 & 0.076 & 0.074 & 0.079 \\ (0.097) & (0.096) & (0.096) & (0.096) \\ \bullet & \bullet & \bullet & \bullet \\ 0.006 & 0.009 & 0.005 & 0.006 \\ (0.041) & (0.042) & (0.041) & (0.042) \\ 5.212^{* * *} & 5.183^{* * *} & 6.651 * * * & 5.126^{* * *} \\ (0.280) & (0.282) & (0.225) & (0.274) \\ 1,944 & 1,944 & 1,944 & 1,944 \\ 1,339 & 1,339 & 1,339 & 1,339 \\ 0.208 & 0.208 & 0.212 & 0.212\end{array}$

0.212

0.212

Notes: Cluster-robust standard errors in parentheses; ${ }^{* * *} \mathrm{p}<0.01,{ }^{*} \mathrm{p}<0.05,{ }^{*} \mathrm{p}<0.10, \bullet$ Reference category

Please note that the interaction term in model (3) and (4) are demeaned, so that the linear terms capture the effect at the mean.

\subsection{Sensitivity Analysis: Selection Bias and Propensity Score Matching}

A potential drawback of the random effects estimation described in the previous paragraphs is that the observed effect of SNS use can result from the self-selection of individuals into SNS use. What would the results mean if unhappy young adults who experience social loneliness heavily use SNS to substitute their real-life contacts? This is possible because lonely people tend to use SNS more frequently (Kim et al. 2012; Song 2015). However, under these conditions, the level of happiness that lonely individuals would have reported if they had not used SNS extensively remains unclear. In other words, specific personal characteristics can predispose young adults to self-select into SNS use.

Propensity score matching (Rosenbaum and Rubin 1983; Caliendo and Kopeinig 2008) reduces this selection bias by comparing the happiness of excessive SNS users to that of non-excessive SNS users who are as similar as possible in all other respects (Becker and Ichino 2002) and has recently been applied in other happiness studies (e.g., Binder and Coad 2013, Nikolova and Graham 2014, Tiefenbach and Kohlbacher 2014, Hessels et al. 2015). This statistical technique can best be compared to a randomized control trial in which two groups of individuals are randomly assigned to the treatment under study or to a control group. In our case, the treatment is excessive SNS use, which 
is defined as the highest 10th percentile of the distribution and exceeding 10 hours per week, on average (approximately more than $1 \mathrm{SD}$ above the mean). The effect of the treatment is referred to as the average treatment effect on the treated (ATT), and in our case, it can be defined as the difference between excessive and non-excessive users of SNS in their expected happiness.

However, as indicated by Shadish et al. (2002), it is challenging to find exact matches when matching for multiple individual characteristics. Hence, propensity score matching variables are often combined into a multivariate composite that is utilized to match untreated individuals to treated individuals. In the present research, we used the 5-nearest neighbour matching estimator, which is often used in propensity score matching (Becker and Ichino 2002). We chose this matching estimator because we had many comparable untreated respondents in our sample (Caliendo and Kopeinig 2008). The Gaussian kernel estimator, which is also often used when working with this type of data, was not applied here because not all of the groupings met the common support assumption of this estimator. ${ }^{10}$ The respondents were matched using a probit model that included the following matching variables: gender, age, marital status, level of education, occupational status, household income, the time spent on Internet activities, and other dimensions of individual social capital. In addition to the estimation for the total sample, we estimated the propensity for eight groups with a high or low quality of social capital based on our social isolation and loneliness variables. We estimated the AT'Ts for the eight subgroups that resulted from the division of individuals based on their quantity and quality of social capital. The eight subgroups were based on (1) infrequent vs. frequent contacts

\footnotetext{
${ }^{10}$ It should be noted that propensity score matching relies on the following two main assumptions: the unconfoundedness of control variables and the common support. The first implies that the control variables used to match the observations in our sample capture all of the differences between those who use SNS excessively and those who do not and, thus, any observed differences in happiness levels are attributable to the use of SNS. The latter assumption, which is testable, assumes that individuals (observations) with same characteristics have equal probabilities of belonging to either of the two SNS-use groups (i.e., excessive users vs. non-excessive users). After the test was run, the results for the 5 -nearest neighbour matching showed that this assumption was most often not violated because the bias of each single variable in all estimations slightly exceeded the 10\% threshold only in a few cases (D'Agostino 1998). These test statistics are available upon request.
} 
with friends, (2) infrequent vs. frequent contact with family, (3) dissatisfaction with contacts (ratings lower than 7) vs. satisfaction with contacts (ratings of 7 or above), and (4) feeling lonely (social loneliness index of 3 or higher) vs. not feeling lonely (social loneliness index of lower than 3).

The main results of the propensity score matching are presented in Table 5 and are broadly in line with our random effects regressions. Based on our estimation for the total sample (Row 1), we found that young adults who used SNS excessively (10 hours or more per week) were not significantly less happy than young adults who only used SNS to a limited extent. Consistent with our findings from the random effects regression, the greatest differences in happiness between excessive and nonexcessive SNS users were found within the group of young adults that was characterized by a high degree of social loneliness. In other words, excessive SNS use has a stronger negative association with happiness within the group of people with a low quality of social capital than within the group of people with a high quality of social capital. Within the group of young adults who were dissatisfied with their social contacts, the happiness of excessive SNS users was approximately 1.20 points lower than that of non-excessive users. Within the group of young adults who scored high on the social loneliness index, the happiness of excessive SNS users was approximately 0.87 points lower than that of non-excessive users. When the ATT within subgroups was compared, we found that within the groups that had infrequent contact with family or friends, excessive SNS users were not significantly less happy than non-excessive SNS users. Likewise, within the groups that were characterized by a high quantity and quality of social capital, excessive SNS users were not significantly less happy than non-excessive SNS users. 
Table 5: Average Treatment to the Treated: Closest five neighbours matching method

\begin{tabular}{|c|c|c|c|}
\hline Closest five neighbours matching method & Treated & Untreated & Difference \\
\hline Total sample & 7.186 & 7.392 & $\begin{array}{l}-0.206 \\
(0.134)\end{array}$ \\
\hline Infrequent Contact with Friends & 7.048 & 7.180 & $\begin{array}{l}-0.132 \\
(0.324)\end{array}$ \\
\hline Frequent Contact with Friends & 7.228 & 7.381 & $\begin{array}{l}-0.153 \\
(0.145)\end{array}$ \\
\hline Infrequent Contact with Family & 6.703 & 7.103 & $\begin{array}{l}-0.400 \\
(0.337)\end{array}$ \\
\hline Frequent Contact with Family & 7.314 & 7.493 & $\begin{array}{l}-0.179 \\
(0.140)\end{array}$ \\
\hline Less Satisfied with Contacts & 5.618 & 6.824 & $\begin{array}{l}-1.206 * * * \\
(0.383)\end{array}$ \\
\hline Satisfied with Contacts & 7.559 & 7.596 & $\begin{array}{l}0.037 \\
(0.137)\end{array}$ \\
\hline Lonely & 6.083 & 6.954 & $\begin{array}{l}-0.871 * * * \\
(0.330)\end{array}$ \\
\hline Not Lonely & 7.597 & 7.504 & $\begin{array}{l}0.093 \\
(0.119)\end{array}$ \\
\hline
\end{tabular}

\section{Discussion and Conclusion}

In this article, we examined the extent to which online interactions on SNSs might be replacing traditional face-to-face interactions as a source of happiness for young adults (15-44 years old). Starting with the observation that young people increasingly use SNSs in everyday life, the extent to which and conditions under which SNS affects happiness remain largely unknown. Subsequently, we examined the extent to which the effect of SNS on happiness is moderated by individual social capital, as measured in terms of social isolation and loneliness. Here, we considered both whether the respondents were physically disconnected from their friends (quantity of individual social capital) and whether they felt lonely and dissatisfied with their social contacts (quality of individual social capital). 
Our main results showed that time spent on SNSs had a negative but insignificant effect on happiness for the total sample. This finding is in line with the studies of Helliwell and Huang (2013) and Lönnqvist and Itkonen (2014), who also did not find a relationship between SNS use and subjective well-being. At the same time, both the quantity and quality of social relationships were positively associated with happiness in our study, whereas SNSs did not affect the relationship between individual social capital and happiness. Overall, these findings support the view that SNSs are not a substitute for real-life social connections in terms of happiness and, at most, complement these connections.

Nevertheless, we found a negative association between the number of hours spent on SNSs and subjective well-being for SNS users who experienced feelings of loneliness and dissatisfaction with their contacts. Although there is no relationship between excessive SNS use and happiness for young adults with a high quality of individual social capital, excessive SNS use negatively affects the happiness of individuals who feel lonely and dissatisfied with their social contacts. These findings echo earlier research by Jin et al. (2013), who found that lonely people are more dissatisfied with SNS as a communication platform. At the same time, the quantity of social capital, as measured in terms of the frequency of meetings with friends or family, did not moderate the relationship between SNS use and happiness.

In sum, our findings highlight that the relationship between SNS use and happiness is very nuanced and heterogeneous in nature, which also explains (in part) the conflicting findings regarding the relationship between happiness and SNS use in the present literature. Our study underlines the fact that it is pivotal to examine for which type of people and under which conditions SNS use is conducive or detrimental to happiness and other facets of subjective well-being. 


\subsection{Limitations and Future Research}

Regarding the heterogeneity of the relationship between SNS use and happiness, a limitation of our study is that we only examined individual social capital as a moderator. There could be other factors that moderate the relationship between SNS use and happiness. Most notably, our data regarding SNS use do not provide detailed information about how the participants spent their time on SNSs, which is a major limitation when discussing the implications in terms of social capital-based comparisons. Specifically, the average time spent online only accounts for the duration of SNS activity and not for the purposes of using such networks. For example, the participants did not report how much time they spent sharing their own activities online compared with the time they spent observing the activities of others. In this regard, recent research by Wenninger et al. (2014) suggests that while active participation on SNSs is positively associated with subjective well-being, passive following generally has the opposite effect (see also Lin and Utz 2015). Likewise, future research could further distinguish between the different types of SNS platforms. For example, the relationship between Twitter use and happiness might be different from the relationship between Facebook use and happiness.

Furthermore, we lack detailed information about the personality (see Lönnqvist and \& große Deters 2016) as well as the emotions that young adults experience when using SNSs. Specifically, it would be interesting to examine the interplay among social loneliness, envy, inauthenticity, and happiness. In this regard, several studies have focused on negative emotions experienced, such as envy (Krasnova et al. 2013; Muise et al. 2009; Tandoc et al. 2015; Utz and Beukeboom 2011) and inauthenticity (Reinecke and Trepte 2013). However, research in which these factors are jointly examined is currently lacking in the literature on SNS and happiness. In addition, future research 
should address the positive emotions that can be experienced when using SNS to examine under which conditions SNSs are conducive to subjective well-being.

Finally, this study has a number of limitations with regard to the data that were utilized that should be addressed in future research. First, because the participants only reported the time that they spent online and did not indicate their number of online connections compared with real-life interactions, our conclusion that SNS is not a substitute in terms of happiness for conventional means of social interaction needs further examination. Second, our study focused only on global judgements of subjective well-being and did not take into account other measures of subjective well-being, such as positive affect. Third, SNS use was measured in terms of the time spent on SNSs. Although this is likely the most common way to measure SNS use in the empirical literature, such self-reported measures of SNS use are subject to memory distortions (Pantic et al. 2012). Alternatively, a time use and diary research (see also Kross et al. 2014) could be used to examine the association between SNS use and SWB.

Although we find no relationship between SNS use and happiness among young adults in the Netherlands, it appears that SNSs can negatively affect the happiness of people who experience a low quality of social contacts. These findings imply that it would be better for individuals with a low quality of social capital to avoid intensive use SNS platforms because these platforms may further lower their happiness level. At the same time, following this advice could create a Catch-22 situation because SNSs may be one of the only ways for these people to maintain contact with others. In this regard, it would be important to address how people use SNSs. It may well be that lonely users who chat frequently on SNSs gain happiness from spending time online, whereas lonely users who spend most of their time scrolling through other people's profiles become less happy. However, more research is needed to verify this claim. 


\section{Bibliography}

Adam, F. (2008). Mapping social capital across Europe: Findings, trends and methodological shortcomings of cross-national surveys. Social Science Information, 47(2), 159-186.

Antheunis, M. L., Valkenburg, P. M., \& Peter, J. (2010). Getting acquainted through social network sites: Testing a model of online uncertainty reduction and social attraction. Computers in Human Behavior, 26(1), 100-109.

Appel, H., Gerlach, A. L., \& Crusius, J. (2016). The interplay between Facebook use, social comparison, envy, and depression. Current Opinion in Psychology, 9(June 2016), 44-49.

Ateca-Amestoy, V., Aguilar, A. C., \& Moro-Egido, A. I. (2014). Social interactions and life satisfaction: Evidence from Latin America. Journal of Happiness Studies, 15(3), 527-554.

Bazarova, N. N. (2012). Public intimacy: Disclosure interpretation and social judgments on facebook. Journal of Communication, 62(5), 815-832.

Becker, S. O., \& Ichino, A. (2002) Estimation of average treatment effects based on propensity scores. The Stata Journal, 2(4), 358-377.

Boyd, D. M., \& Ellison, N. B. (2007). Social network sites: Definition, history, and scholarship. Journal of Computer-Mediated Communication, 13(1), 210-230.

Binder, M., \& Coad, A. (2013). Life satisfaction and self-employment: A matching approach. Small Business Economics, 40(4), 1009-1033.

Cacioppo, J. T., \& Patrick, W. (2008). Loneliness: Human nature and the need for social connection WW Norton \& Company.

Caliendo, M., \& Kopeinig, S. (2008). Some practical guidance for the implementation of propensity score matching. Journal of Economic Surveys, 22(1), 31-72

Chou, H. G., \& Edge, N. (2012). "They are happier and having better lives than I am": The impact of using facebook on perceptions of others' lives. Cyberpsychology, Behavior, and Social Networking, 15(2), 117-121.

D’Agostino, R. B. (1998). Tutorial in biostatistics: Propensity score methods for bias reduction in the comparison of a treatment to a non-randomized control group. Statistics in Medicine, 17(19), 2265-2281.

De Jong Gierveld, J., Van Tilburg, T., \& Dykstra, P. A. (2006). Loneliness and social isolation. In A. L. Vangelisti \& D. Perlman (eds), Cambridge Handbook of Personal Relationships. Cambridge, UK: Cambridge University Press, pp. 485-500.

De Jong Gierveld, J., \& Van Tilburg, T. (2006). A 6-item scale for overall, emotional, and social loneliness confirmatory tests on survey data. Research on Aging, 28(5), 582-598.

De Jong Gierveld, J., \& Van Tilburg, T. (2010). The de Jong Gierveld short scales for emotional and social loneliness: Tested on data from 7 countries in the UN generations and gender surveys. European Journal of Ageing, 7(2), 121-130.

Diener, E., Suh, E. M., Lucas, R. E., \& Smith, H. L. (1999). Subjective well-being: Three decades of progress. Psychological Bulletin, 125(2), 276-302. 
Ellison, N. B., Steinfield, C., \& Lampe, C. (2007). The benefits of Facebook "friends:" social capital and college students' use of online social network sites. Journal of Computer-Mediated Communication, 12(4), 1143-1168.

Ernst, J. M., \& Cacioppo, J. T. (1999). Lonely hearts: Psychological perspectives. Applied \& Preventive Psychology, 8(1), 1-22.

Forest, A. L., \& Wood, J. V. (2012). When social networking is not working: Individuals with low self-esteem recognize but do not reap the benefits of self-disclosure on facebook. Psychological Science, 23(3), 295-302.

Forsman, A. K., Nyqvist, F., Schierenbeck, I., Gustafson, Y., \& Wahlbeck, K. (2012). Structural and cognitive social capital and depression among older adults in two Nordic regions. Aging \& Mental Health, 16(6), 771-779.

Helliwell, J. F., \& Barrington-Leigh, C. P. (2010). How much is social capital worth?, In J. Jetten, C. Haslam, \& S.A. Haslam (eds), The Social Cure, London: Psychology Press, pp. 55-71.

Helliwell, J. F., \& Huang, H. (2013). Comparing the happiness effects of real and on-line friends. PloS One, 8(9), e72754.

Hessels J., Arampatzi E., van der Zwan P., \& Burger M.J. (2015). Life satisfaction of the selfemployed for different types of occupations. Working Paper, Erasmus University Rotterdam.

Hox, J. J. (2002). Multilevel Analysis: Techniques and Applications. Psychology Press.

Jin, B. (2013). How lonely people use and perceive Facebook. Computers in Human Behavior, 29(6), 2463-2470.

Johnston, K., Tanner, M., Lalla, N., \& Kawalski, D. (2013). Social capital: The benefit of Facebook 'friends'. Behaviour \& Information Technology, 32(1), 24-36.

Kim, J., \& Lee, J. R. (2011). The Facebook paths to happiness: Effects of the number of Facebook friends and self-presentation on subjective well-being. Cyberpsychology, Behavior, and Social Networking, 14(6), 359-364.

Kim, J.Y., Chung, N. and Ahn, K.M. (2013). Why People Use Social Networking Services in Korea the Mediating Role of Self-Disclosure on Subjective Well-Being. Information Development, 1-12.

Krasnova, H., Wenninger, H., Widjaja, T., \& Buxmann, P. (2013). Envy on Facebook: A hidden threat to users' life satisfaction? International Conference on Wirtschaftsinformatik (WI) / Business Information Systems 2013, Leipzig, Germany.

Kraut, R., Kiesler, S., Boneva, B., Cummings, J., Helgeson, V., \& Crawford, A. (2002). Internet paradox revisited. Journal of Social Issues, 58(1), 49-74.

Kraut, R., Patterson, M., Lundmark, V., Kiesler, S., Mukophadhyay, T., \& Scherlis, W. (1998). Internet paradox: A social technology that reduces social involvement and psychological well-being? American Psychologist, 53(9), 1017.

Kross, E., Verduyn, P., Demiralp, E., Park, J., Lee, D. S., Lin, N., et al. (2013). Facebook use predicts declines in subjective well-being in young adults. PloS One, 8(8), e69841.

Layard, R. (2005). Happiness: Lessons form a new science. London: Allen Lane,

Leary, M. R. (1990). Responses to social exclusion: Social anxiety, jealousy, loneliness, depression, and low self-esteem. Journal of Social and Clinical Psychology, 9(2), 221-229. 
Lee, K.-T., Noh, M.-J. and Koo, D.-M. (2013). Lonely People Are No Longer Lonely on Social Networking Sites: The Mediating Role of Self-Disclosure and Social Support. Cyberpsychology, Behavior, and Social Networking, 16 (6), 413-418.

Lin, R., \& Utz, S. (2015). The emotional responses of browsing Facebook: Happiness, envy, and the role of tie strength. Computers in Human Behavior, 52, 29-38.

Locatelli, S.M., Kluwe, K. and Bryant, F.B. (2012). Facebook use and the tendency to ruminate among college students: testing mediational hypotheses. Journal of Educational Computing Research, 46 (4), 377-394.

Lönnqvist, J. E., \& große Deters, F. (2016). Facebook friends, subjective well-being, social support, and personality. Computers in Human Behavior, 55 - Part A (February 2016), 113-120.

Lönnqvist, J. E., \& Itkonen, J. V. (2014). It's all about extraversion: Why Facebook friends doesn't count towards well-being. Journal of Research in Personality, 53, 64-67.

Lyubomirsky, S., Tkach, C., \& DiMatteo, M. R. (2006). What are the differences between happiness and self-esteem. Social Indicators Research, 78(3), 363-404.

Manago, A. M., Taylor, T., \& Greenfield, P. M. (2012). Me and my 400 friends: The anatomy of college students' Facebook networks, their communication patterns, and well-being. Developmental Psychology, 48(2), 369.

McPherson, M., Smith-Lovin, L., \& Brashears, M. E. (2006). Social isolation in america: Changes in core discussion networks over two decades. American Sociological Review, 71(3), 353-375.

Muise, A., Christofides, E., \& Desmarais, S. (2009). More information than you ever wanted: Does Facebook bring out the green-eyed monster of jealousy? CyberPsychology \& Behavior, 12(4), 441-444.

Nikolova, M., \& Graham, C. (2014) Employment, late-life work, retirement, and well-being in Europe and the United States. IZA Journal of European Labor Studies, 3(5).

Ninivaggi, M. J. D. (2010). Envy theory: Perspectives on the psychology of envy Rowman \& Littlefield Publishers.

Qiu, L., Lin, H., Leung, A. K., \& Tov, W. (2012). Putting their best foot forward: Emotional disclosure on facebook. Cyberpsychology, Behavior, and Social Networking, 15(10), 569-572.

Pantic, I., Damjanovic, A., Todorovic, J., Topalovic, D., Bojovic-Jovic, D., Ristic, S., \& Pantic, S. (2012). Association between online social networking and depression in high school students: behavioral physiology viewpoint. Psychiatria Danubina, 24(1), 90-93.

Portela, M., Neira, I., \& del Mar Salinas-Jiménez, M. (2013). Social capital and subjective wellbeing in Europe: A new approach on social capital. Social Indicators Research, 114(2), 493-511.

Portes, A. (2000). The two meanings of social capital. Sociological Forum, 15(1), 1-12.

Putnam, R. D. (2000). Bowling alone: Civic disengagement in America. New York.

Reinecke, L., \& Trepte, S. (2014). Authenticity and well-being on social network sites: A two-wave longitudinal study on the effects of online authenticity and the positivity bias in SNS communication. Computers in Human Behavior, 30, 95-102.

Rodríguez-Pose, A., \& von Berlepsch, V. (2014). Social capital and individual happiness in Europe. Journal of Happiness Studies, 15(2), 357-386. 
Rosenbaum, P.R., \& Rubin, D.B. (1983). The central role of the propensity score in observational studies for causal effects. Biometrika, 70(1), 41-55.

Sabatini, F., \& Sarracino, F. (2014). Will Facebook save or destroy social capital. An empirical investigation into the effect of online interactions on trust and networks. EERI Research Paper Series EERI RP, 2

Sagioglou, C., \& Greitemeyer, T. (2014). Facebook's emotional consequences: Why Facebook causes a decrease in mood and why people still use it. Computers in Human Behavior, 35, 359-363.

Sarracino, F. (2010). Social capital and subjective well-being trends: Comparing 11 Western European countries. The Journal of Socio-Economics, 39(4), 482-517.

Shadish, W. R., Cook, T. D., \& Campbell, D. T. (2002). Experimental and Quasi-Experimental Design for Generalized Causal Inference. Boston: Houghton-Mifflin.

Scheepers, P., \& Janssen, J. (2003). Informal aspects of social capital: Developments in the Netherlands 1970-1998. Netherlands Journal of Social Sciences, 39(2), 87-106.

Schoeck, H. (1969). Envy; A Theory of Social Behavior. Indianapolis: Liberty Press.

Song, H., Zmyslinski-Seelig, A., Kim, J., Drent, A., Victor, A., Omori, K., et al. (2014). Does Facebook make you lonely?: A meta analysis. Computers in Human Behavior, 36, 446-452.

Steinfield, C., Ellison, N. B., \& Lampe, C. (2008). Social capital, self-esteem, and use of online social network sites: A longitudinal analysis. Journal of Applied Developmental Psychology, 29(6), 434-445.

Tandoc Jr., E. C., Ferrucci, P., \& Duffy, M. (2015). Facebook use, envy, and depression among college students: Is Facebooking depressing? Computers in Human Behavior, 43, 139-146.

Tiefenbach, T., \& Kohlbacher, F. (2014). Happiness in Japan in times of upheaval: empirical evidence from the national survey on lifestyle preferences. Journal of Happiness Studies (forthcoming).

Toepoel, V. (2013). Ageing, leisure, and social connectedness: How could leisure help reduce social isolation of older people? Social Indicators Research, 113(1), 355-372.

Turkle, S. (2012). Alone Together: Why We Expect More from Technology and Less from Each Other. New York: Basic books.

Utz, S. (2011). Social network site use among Dutch students: Effects of time and platform. Networked sociability and individualism. Technology for personal and professional relationships, 103-125.

Utz, S., \& Beukeboom, C. J. (2011). The role of social network sites in romantic relationships: Effects on jealousy and relationship happiness. Journal of Computer-Mediated Communication, 16(4), 511-527.

Valenzuela, S., Park, N., \& Kee, K. F. (2009). Is there social capital in a social network site?: Facebook use and college students' life satisfaction, trust, and participation1. Journal of Computer-Mediated Communication, 14(4), 875-901.

Van der Horst, M., \& Coffé, H. (2012). How friendship network characteristics influence subjective well-being. Social Indicators Research, 107(3), 509-529.

Veenhoven, R. (2015). Informed pursuit of happiness: What we should know, do know and can get to know. Journal of Happiness Studies, 16(4), 1035-1071. 
Wang, S.S. (2013). "I Share, Therefore I Am": Personality Traits, Life Satisfaction, and FacebookCheckIns. Cyberpsychology, Behavior, and Social Networking, 16 (12), 870-877.

Wenninger, H., Krasnova, H., \& Buxmann, P. (2014). Activity matters: Investigating the influence of Facebook on life satisfaction of teenage users. Working paper.

Wise, K., Alhabash, S., \& Park, H. (2010). Emotional responses during social information seeking on Facebook. Cyberpsychology, Behavior, and Social Networking, 13(5), 555-562. 


\section{Appendix A:}

Table 1: Descriptions of the Variables Included in the Analysis

\begin{tabular}{|c|c|c|c|}
\hline Dependent Variables & Measure & Question & Answer Categories \\
\hline Happiness & $0-10$ & $\begin{array}{l}\text { On the whole, how happy } \\
\text { would you say you are? } 0 \text { is } \\
\text { equal to "totally unhappy" } \\
\text { and } 10 \text { to "totally happy". }\end{array}$ & $0-10$ \\
\hline Time spent on & $\begin{array}{l}\text { Continuous: Average } \\
\text { number of hours spent } \\
\text { (per week) }\end{array}$ & $\begin{array}{l}\text { Please indicate how many } \\
\text { hours per week, on average, } \\
\text { you spend on these online } \\
\text { activities: (a) On one or any } \\
\text { of the following social } \\
\text { network sites: Facebook, } \\
\text { Hyves, Myspace, } \\
\text { Sugababes, or others, (b) } \\
\text { Twitter, and (c) dating sites } \\
\text { (such as Relatieplanet, Lexa, } \\
\text { or others). }\end{array}$ & \\
\hline \multicolumn{4}{|l|}{$\begin{array}{l}\text { Individual Social } \\
\text { Capital }\end{array}$} \\
\hline \multicolumn{4}{|l|}{ Social Isolation } \\
\hline $\begin{array}{l}\text { Frequency of spending } \\
\text { an evening with family }\end{array}$ & $\begin{array}{l}\text { Frequent-Infrequent } \\
0-1\end{array}$ & $\begin{array}{l}\text { How often do you do the } \\
\text { following: spend an evening } \\
\text { with family (other than } \\
\text { members of your own } \\
\text { household)? }\end{array}$ & $\begin{array}{l}\text { (1) Almost every day, (2) once } \\
\text { or twice per week, (3) a few } \\
\text { times per month, (4) about } \\
\text { once per month, (5) a number } \\
\text { of times per year, (6) about } \\
\text { once per year, (7) never, (8) } \\
\text { don't know, or (9) not } \\
\text { applicable. }\end{array}$ \\
\hline $\begin{array}{l}\text { Frequency of spending } \\
\text { an evening with friends }\end{array}$ & $\begin{array}{l}\text { Frequent-Infrequent } \\
0-1\end{array}$ & $\begin{array}{l}\text { How often do you do the } \\
\text { following: spend an evening } \\
\text { with friends (outside your } \\
\text { neighbourhood)? }\end{array}$ & $\begin{array}{l}\text { (1) Almost every day, (2) once } \\
\text { or twice per week, (3) a few } \\
\text { times per month, (4) about } \\
\text { once per month, (5) a number } \\
\text { of times per year, (6) about } \\
\text { once per year, (7) never, (8) } \\
\text { don't know, or (9) not } \\
\text { applicable. }\end{array}$ \\
\hline \multicolumn{4}{|l|}{ Subjective Measures } \\
\hline Social Loneliness Index & $0-6$ & $\begin{array}{l}\text { (i) There are enough people } \\
\text { I can count on in case of a } \\
\text { misfortune, (ii) I know } \\
\text { many people on whom I } \\
\text { can completely rely, and (iii) } \\
\text { There are enough people to } \\
\text { whom I feel closely } \\
\text { connected. }\end{array}$ & $\begin{array}{l}\text { (i) Yes/Don't know/No } \\
\text { (ii) Yes/Don't know/No } \\
\text { (iii) Yes/Don't know/No }\end{array}$ \\
\hline $\begin{array}{l}\text { Satisfaction with } \\
\text { personal contacts }\end{array}$ & $0-10$ & $\begin{array}{l}\text { How satisfied are you with } \\
\text { your social contacts? }\end{array}$ & $0-10$ \\
\hline \multicolumn{4}{|l|}{ Control Variables } \\
\hline Other Internet use & $\begin{array}{l}\text { Continuous: Average } \\
\text { number of hours spent } \\
\text { (per week) }\end{array}$ & $\begin{array}{l}\text { Please indicate how many } \\
\text { hours per week, on average, }\end{array}$ & \\
\hline
\end{tabular}




\begin{tabular}{|c|c|c|c|}
\hline & & $\begin{array}{l}\text { you spend on these online } \\
\text { activities: other activities }{ }^{11}\end{array}$ & \\
\hline Online gaming & $\begin{array}{l}\text { Continuous: Average } \\
\text { number of hours spent } \\
\text { (per week) }\end{array}$ & $\begin{array}{l}\text { Please indicate how many } \\
\text { hours per week, on average, } \\
\text { you spend on these online } \\
\text { activities: online games. }\end{array}$ & \\
\hline Trust in people & $0-10$ & $\begin{array}{l}\text { Generally speaking, would } \\
\text { you say that most people } \\
\text { can be trusted or that you } \\
\text { cannot be too careful in } \\
\text { dealing with people? Please } \\
\text { indicate a score of } 0 \text { to } 10 .\end{array}$ & \\
\hline Gender & $0-1$ & Gender & Female-Male \\
\hline Age groups & $1,2,3$ & Age & $15-24$ years old, $25-34,35-44$ \\
\hline Occupation & $1,2,3,4$ & Primary occupation & $\begin{array}{l}\text { Pension ,Unemployed, } \\
\text { Employed, School }\end{array}$ \\
\hline Civil status & $1,2,3$ & Civil status & $\begin{array}{l}\text { Single, Married, } \\
\text { Separated/Divorced/Widowed }\end{array}$ \\
\hline $\begin{array}{l}\text { Household income } \\
(1000)\end{array}$ & $\begin{array}{l}\text { Continuous: Income in } \\
\text { euros } * 100\end{array}$ & $\begin{array}{l}\text { Household income in } \\
\text { Euros }\end{array}$ & \\
\hline Level of education & $1,2,3$ & $\begin{array}{l}\text { Highest level of education } \\
\text { with diploma }\end{array}$ & $\begin{array}{l}\text { Low Education (ISCED 1-2), } \\
\text { Medium Education (ISCED 3- } \\
\text { 4), High Education (ISCED 5- } \\
\text { 6) }\end{array}$ \\
\hline Year & & $\begin{array}{l}\text { Year in which the survey } \\
\text { took place }\end{array}$ & 2012,2013 \\
\hline
\end{tabular}

\footnotetext{
${ }^{11}$ Such activities include hours spent emailing, searching for information on the Internet (e.g., about hobbies, work, business hours, and day trips); searching for and comparing products/product information on the Internet; purchasing items via the Internet; watching short films (e.g., via YouTube) or watching online films or TV programs; downloading software, music or films; Internet banking; reading online news and magazines; newsgroups; reading and/or writing blogs; Skype or similar services; chatting/MSN; Twitter; dating websites; visiting forums and Internet communities; other activities on the Internet.
} 
Table 2: Frequencies of Categorical Variables in Sample

\begin{tabular}{|c|c|c|c|}
\hline & Frequency & Percent & Cum \\
\hline \multicolumn{4}{|l|}{ Independent variables } \\
\hline Infrequent contact with friends & 1336 & 68.7 & 68.7 \\
\hline Frequent contact with friends & 608 & 31.3 & 100 \\
\hline Infrequent contact with family & 1549 & 79.7 & 79.7 \\
\hline Frequent contact with family & 395 & 20.3 & 100.0 \\
\hline \multicolumn{4}{|l|}{ Gender } \\
\hline Male & 801 & 41.2 & 41.2 \\
\hline Female & 1143 & 58.8 & 100.0 \\
\hline \multicolumn{4}{|l|}{ Age groups } \\
\hline $15-24$ years old & 611 & 31.4 & 31.4 \\
\hline 25-34 years old & 602 & 31.0 & 62.4 \\
\hline $35-44$ years old & 731 & 37.6 & 100.0 \\
\hline \multicolumn{4}{|l|}{ Occupational status } \\
\hline Pension & 144 & 7.4 & 7.4 \\
\hline Unemployed & 51 & 2.6 & 10.0 \\
\hline Employed & 1233 & 63.4 & 73.4 \\
\hline School & 516 & 26.5 & 100.0 \\
\hline \multicolumn{4}{|l|}{ Civil status } \\
\hline Single & 1223 & 62.9 & 62.9 \\
\hline Married & 648 & 33.3 & 96.2 \\
\hline Separated/Divorced/Widowed & 73 & 3.8 & 100.0 \\
\hline \multicolumn{4}{|l|}{ Education } \\
\hline Low level & 391 & 20.1 & 20.1 \\
\hline Medium level & 854 & 43.9 & 64.0 \\
\hline High level & 699 & 36.0 & 100.0 \\
\hline \multicolumn{4}{|l|}{ Year } \\
\hline 2012 & 1002 & 51.5 & 51.5 \\
\hline 2013 & 942 & 48.5 & 100.0 \\
\hline
\end{tabular}


Appendix B: Treating Social Capital as a Continuous Indicator

Table 1: Random effects estimation: SNS, Individual Social Capital as Continuous, and SWB

\begin{tabular}{lcccccc}
\hline & $(1)$ & $(2)$ & $(3)$ & $(4)$ & $(5)$ & $(6)$ \\
\hline Time spent on social network sites (x10h) & -0.022 & -0.024 & -0.025 & -0.042 & -0.014 & -0.037 \\
& $(0.061)$ & $(0.061)$ & $(0.060)$ & $(0.053)$ & $(0.058)$ & $(0.053)$ \\
Contact with friends (continuous) & & -0.073 & & & & 0.039 \\
& & $(0.055)$ & & & & $(0.053)$ \\
Contact with family (continuous) & & & $-0.196^{* * *}$ & & & -0.101 \\
& & & $(0.067)$ & & & $(0.066)$ \\
Satisfaction with social contacts & & & & $0.227 * * *$ & & $0.207 * * *$ \\
& & & & $(0.023)$ & & $(0.025)$ \\
Social loneliness index & & & & & $-0.106^{* * *}$ & $-0.042^{* *}$ \\
& -0.002 & -0.002 & 0.005 & -0.019 & 0.053 & $(0.017)$ \\
Year: 2013 & $(0.040)$ & $(0.040)$ & $(0.040)$ & $(0.039)$ & $(0.041)$ & $(0.008$ \\
& YES & YES & YES & YES & YES & YES \\
Personal characteristics & YES & YES & YES & YES & YES & YES \\
Demographics & YES & YES & YES & YES & YES & YES \\
Other time spent online & $(0.095)$ & $(0.095)$ & $(0.095)$ & $(0.088)$ & $(0.093)$ & $(0.088)$ \\
& $6.294^{* * *}$ & $6.330^{* * *}$ & $6.350^{* * *}$ & $4.976^{* * *}$ & $6.529^{* * *}$ & $5.198^{* * *}$ \\
Constant & $(0.240)$ & $(0.239)$ & $(0.239)$ & $(0.267)$ & $(0.236)$ & $(0.280)$ \\
& 1,944 & 1,944 & 1,944 & 1,944 & 1,944 & 1,944 \\
Observations & 1,339 & 1,339 & 1,339 & 1,339 & 1,339 & 1,339 \\
Number of IDs & & & & & & \\
& & & & & &
\end{tabular}

Robust standard errors in parentheses

$$
\text { *** } \mathrm{p}<0.01,{ }^{* *} \mathrm{p}<0.05,{ }^{*} \mathrm{p}<0.1
$$


Table 2: Random effects estimation: SNS and SWB. Moderation Analysis: 1) Frequency of contacts with family as continuous 2 ) Frequency of contacts with friends as continuous 3 ) Satisfaction with contacts 4) Social Loneliness Index

\begin{tabular}{|c|c|c|c|c|}
\hline Infreguent contact with friends continuouc)* & $\begin{array}{ll}0 \\
(1)\end{array}$ & $(2)$ & (3) & (4) \\
\hline Time spent on online social networks (x10h) & 0.128 & & & \\
\hline $\begin{array}{l}\text { Infrequent contact with family continuous)* } \\
\text { Time spent on online social networks (x10h) }\end{array}$ & & -0.079 & & \\
\hline $\begin{array}{l}\text { Satisfaction with contacts* Time spent on online } \\
\text { social networks ( } \mathrm{x} 10 \mathrm{~h})\end{array}$ & & & $\begin{array}{c}0.065^{* *} \\
(0.027)\end{array}$ & \\
\hline $\begin{array}{l}\text { Social loneliness index* Time spent on online } \\
\text { social networks }(\mathrm{x} 10 \mathrm{~h})\end{array}$ & & & & $\begin{array}{c}-0.053^{* *} \\
(0.021)\end{array}$ \\
\hline Time spent on online social networks (x10h) & $\begin{array}{l}-0.066 \\
(0.054)\end{array}$ & $\begin{array}{l}-0.020 \\
(0.054)\end{array}$ & $\begin{array}{c}-0.498^{* *} \\
(0.208)\end{array}$ & $\begin{array}{c}0.063 \\
(0.058)\end{array}$ \\
\hline Infrequent with friends (continuous) & $\begin{array}{l}-0.025 \\
(0.022)\end{array}$ & $\begin{array}{l}-0.026 \\
(0.022)\end{array}$ & $\begin{array}{l}-0.026 \\
(0.021)\end{array}$ & $\begin{array}{l}-0.027 \\
(0.022)\end{array}$ \\
\hline Infrequent with family (continuous) & $\begin{array}{l}-0.066 \\
(0.089)\end{array}$ & $\begin{array}{l}-0.059 \\
(0.089)\end{array}$ & $\begin{array}{l}-0.069 \\
(0.086)\end{array}$ & $\begin{array}{l}-0.066 \\
(0.087)\end{array}$ \\
\hline Satisfaction with social contacts & $\begin{array}{l}-0.014 \\
(0.067)\end{array}$ & $\begin{array}{c}0.037 \\
(0.053)\end{array}$ & $\begin{array}{c}0.036 \\
(0.053)\end{array}$ & $\begin{array}{c}0.039 \\
(0.052)\end{array}$ \\
\hline Social loneliness index & $\begin{array}{l}-0.098 \\
(0.066)\end{array}$ & $\begin{array}{l}-0.063 \\
(0.084)\end{array}$ & $\begin{array}{l}-0.100 \\
(0.066)\end{array}$ & $\begin{array}{l}-0.104 \\
(0.066)\end{array}$ \\
\hline Year: 2013 & $\begin{array}{l}0.006 \\
(0.041)\end{array}$ & $\begin{array}{c}0.009 \\
(0.041)\end{array}$ & $\begin{array}{l}0.005 \\
(0.041)\end{array}$ & $\begin{array}{c}0.006 \\
(0.042)\end{array}$ \\
\hline Personal characteristics & YES & YES & YES & YES \\
\hline Demographics & YES & YES & YES & YES \\
\hline Other time spent online & YES & YES & YES & YES \\
\hline Constant & $\begin{array}{c}5.212^{* * *} \\
(0.280)\end{array}$ & $\begin{array}{c}5.183^{* * *} \\
(0.282)\end{array}$ & $\begin{array}{c}5.402^{* * *} \\
(0.304)\end{array}$ & $\begin{array}{r}5.142^{* * *} \\
(0.279)\end{array}$ \\
\hline Observations & 1,944 & 1,944 & 1,944 & 1,944 \\
\hline Number of ID & 1,339 & 1,339 & 1,339 & 1,339 \\
\hline
\end{tabular}

Robust standard errors in parentheses $* * * \mathrm{p}<0.01,{ }^{* *} \mathrm{p}<0.05,{ }^{*} \mathrm{p}<0.1$ 